\title{
Effect of follicular diameter, time of first cleavage and H3K4 methylation on embryo production rates of Bos indicus cattle
}

\author{
Efeito do diâmetro folicular, momento da primeira clivagem e \\ metilação da H3K4 na produção embrionária de vacas Bos indicus
}

\author{
Paula Alvares Lunardelli'; Luciana Simões Rafagnin Marinho²; \\ Camila Oliveira Rosa ${ }^{1}$; Amauri Alcindo Alfieri ${ }^{3}$; Marcelo Marcondes Seneda ${ }^{4 *}$
}

\begin{abstract}
This study aimed investigate the relationship between epigenetics, follicular diameter and cleavage speed, by evaluating the developmental potential and occurence of $\mathrm{H} 3 \mathrm{~K} 4$ monomethylation of early-, intermediate- and late-cleaving Bos indicus embryos from in vitro fertilized oocytes originating from follicles up to $2 \mathrm{~mm}$ in diameter or between 4 and $8 \mathrm{~mm}$ in diameter. Oocytes $(\mathrm{n}=699)$ from small follicles $(\leq 2 \mathrm{~mm})$ and 639 oocytes from large follicles $(4-8 \mathrm{~mm})$ were punched from 1,982 Bos indicus' slaughterhouse ovaries. After maturation and in vitro fertilization (IVF), the cultured embryos were separated into early ( $\leq 28 \mathrm{~h}$ post-IVF), intermediate ( $>28 \mathrm{~h}$ and $\leq 34 \mathrm{~h}$ post-IVF) and late ( $>34 \mathrm{~h}$ and $\leq 54 \mathrm{~h}$ post-IVF) cleavage groups. Blastocysts were subjected to an immunofluorescence assessment for H3K4me investigation. The blastocyst rate for large follicles $(36.3 \%)$ was higher than that for small follicles $(22.9 \%, \mathrm{P}<0.05)$. In addition, blastocyst rates for early and intermediate cleavage groups (45.3\% and $33.8 \%$, respectively) were higher than that for late cleavage group $(13.5 \%, \mathrm{P}<0.05)$. The blastocysts from all groups displayed $\mathrm{H} 3 \mathrm{~K} 4$ me staining by immunofluorescence, particularly intense in what seemed to be trophectoderm cells and weak or absent in cells seemingly from the inner cell mass. For the first time for indicus embryos, data from this study demonstrate that higher blastocyst embryo rates are obtained from embryos that cleave within $34 \mathrm{~h}$ after fertilization and from those produced from follicles of 4-8 $\mathrm{mm}$ in diameter, indicating a greater ability of these embryos to develop to the stage of embryonic preimplantation. This is the first article demonstrating the occurrence of H3K4me in cattle embryos; its presence in all the evaluated blastocysts suggests that this histone modification plays a key role in maintaining embryo viability at preimplantation stage.
\end{abstract}

Key words: Bovine. Early cleavage. Follicular size. Late cleavage. Histone modifications.

\section{Resumo}

Este estudo teve como objetivo investigar a relação entre a epigenética, o diâmetro folicular e a velocidade de clivagem, avaliando o potencial de desenvolvimento e a ocorrência de monometilação da H3K4 em embriões Bos indicus de clivagem precoce, intermediária e tardia produzidos a partir de oócitos fertilizados in vitro oriundos de folículos de até $2 \mathrm{~mm}$ de diâmetro ou entre 4 e $8 \mathrm{~mm}$ de diâmetro.

\footnotetext{
${ }^{1}$ Discentes do Curso de Doutorado, Programa de Pós-Graduação em Ciência Animal, Universidade Estadual de Londrina, UEL, Londrina, PR, Brasil. E-mail: palunardelli@hotmail.com; camila_rosa_3@hotmail.com

${ }^{2}$ Pós-Doutorando, Programa de Pós-Graduação em Ciência Animal, UEL, Londrina, PR, Brasil. E-mail: lucianaraf@gmail.com

3 Prof. Dr., Departamento de Medicina Veterinária Preventiva, Centro de Ciências Agrárias, UEL, Londrina, PR, Brasil. E-mail: alfieri@uel.br

${ }^{4}$ Prof. Dr., Departamento de Clínicas Veterinárias, Centro de Ciências Agrárias, UEL, Londrina, PR, Brasil. E-mail: mseneda@ uel.br

* Author for correspondence
} 
Oócitos $(\mathrm{n}=699)$ de folículos pequenos $(\leq 2 \mathrm{~mm})$ e 639 oócitos de folículos grandes $(4-8 \mathrm{~mm})$ foram puncionados de 1982 ovários de vacas Bos indicus de abatedouro. Após a maturação e fertilização in vitro (FIV), os embriões cultivados foram separados nos grupos de clivagem precoce ( $\leq 28 \mathrm{~h}$ pós-FIV), intermediária ( $>28 \mathrm{~h}$ e $\leq 34 \mathrm{~h}$ pós-FIV) e tardia ( $>34 \mathrm{~h} \mathrm{e} \leq 54 \mathrm{~h}$ pós-FIV). Os blastocistos foram submetidos à imunofluorescência para investigação de H3K4me. A taxa de blastocisto para embriões provenientes de folículos grandes $(36,3 \%)$ foi maior que de folículos pequenos $(22,9 \% ; p<0,05)$. Ainda, as taxas de blastocisto para os grupos de clivagem precoce e intermediária (45,3\% e 33,8\%, respectivamente) foram maiores que para o grupo de clivagem tardia $(13,5 \% ; \mathrm{p}<0,05)$. Blastocistos de todos os grupos mostraram marcação para $\mathrm{H} 3 \mathrm{~K} 4$ me à imunofluorescência, particularmente intensa no que pareciam ser células do trofectoderma e fraca ou ausente em células semelhantes às da massa celular interna. Pela primeira vez em embriões indicus, os dados deste estudo demonstram que maiores taxas de blastocisto são obtidas de embriões que clivam em até 34 h pós-fertilização e dos oriundos de folículos de 4 a $8 \mathrm{~mm}$ de diâmetro, indicando uma maior habilidade desses embriões de se desenvolverem até o estágio de pré-implantação embrionária. Este é o primeiro artigo demonstrando a ocorrência de H3K4me em embriões bovinos; sua presença em todos os blastocistos avaliados sugere que essa modificação de histona exerce função-chave na manutenção da viabilidade embrionária no estágio pré-implantação.

Palavras-chave: Bovino. Clivagem precoce. Clivagem tardia. Modificações de histonas. Tamanho folicular.

\section{Introduction}

In vitro embryo production (IVEP) is an increasingly widespread tool which enables multiplying and disseminating high quality genetics and has recently become more accessible. Knowledge regarding the physiology of different species has enabled the development of relatively efficient IVEP protocols for pigs (YOSHIOKA et al., 2012), sheep (AMIRIDIS; CSEH, 2012), goats (RODRÍGUEZ-DORTA et al., 2007) and cattle (PONTES et al., 2011). However, there are many differences between the taurus and indicus subspecies, such as their follicle populations and numbers of oocytes and embryos recovered by ovum pick-up and uterine flushing (CASTRO NETO et al., 2005; PONTES et al., 2010; SILVASANTOS et al., 2014), that directly affect embryo production outcomes. Understanding the subspecies' particularities is crucial for improving the technique, considering that the in vitro culture media are not yet able to exactly mimic the conditions present during in vivo development.

Compared to those generated in vivo, in vitroproduced (IVP) embryos exhibit structural, metabolic and morphological differences, which result in lower rates of development and pregnancy
(CROSIER et al., 2000; FAIR, 2003; SUDANO et al., 2012). The lack of knowledge regarding all the events involved in early embryonic development limits the improvement of culture systems, which is necessary to fully support the embryonic needs and to generate efficient production rates.

A possible explanation for the disparity between the results of in vitro and in vivo embryo production is the source of the oocytes (LEQUARRE et al., 2005). The majority of available ovarian follicles that are punctured during the aspiration process are small follicles; however, during physiological events, the fertilized oocyte comes from a dominant, large follicle (GONÇALVES et al., 2007). However, the exact role of the oocyte source in determining early embryo development is not completely understood (HANSEN et al., 2010), and researchers continue to study follicular size and development and their correlation with oocyte quality in several species (GANJI et al., 2015; KEMPISTY et al., 2014; RODRIGUES et al., 2015; SHABANKAREH et al., 2014).

There is evidence that the speed at which the zygotes undergo their mitotic cycles during cleavage also strongly influences future development (GARCIA et al., 2015). However, there is 
discordance among researchers regarding the ideal length of time for the embryo to complete the first cell cycle (LEQUARRE et al., 2003; SUGIMURA et al., 2012).

The quality that is dictated by oocyte and the embryonic development timing are likely determined by genetic and epigenetic modulation (LABRECQUE et al., 2013; NIVET et al., 2013), which is responsible for governing events that occur in each particular cell.

Epigenetic interactions are very important in oocyte-to-embryo development. There is evidence that histone modification, such as histone 3 lysine $4(\mathrm{H} 3 \mathrm{~K} 4)$ methylation, is essential for cell regulation and molecular events, such as chromatin remodeling and gene expression (RIVERA; ROSS, 2013). H3K4 methylation present in euchromatin seems to be essential for embryonic viability in the preimplantation period likely by playing important roles in the regulation of pluripotency genes (FEIL, 2009; SENEDA et al., 2008). A better understanding of epigenetic processes that influence embryonic development and cell differentiation could contribute to the development of a more efficient embryo production system. However, data regarding epigenetic interactions at $\mathrm{H} 3 \mathrm{~K} 4$ in bovine embryos are scarce in the current literature.

Thus, this study aimed investigate the relationship between epigenetics, follicular diameter and cleavage time, by evaluating the blastocyst rates and distribution of $\mathrm{H} 3 \mathrm{~K} 4$ monomethylation of early-, intermediate- and late-cleaving Bos indicus embryos from in vitro fertilized oocytes originating from follicles up to $2 \mathrm{~mm}$ in diameter or between 4 and $8 \mathrm{~mm}$ in diameter.

\section{Materials and Methods}

This study was performed in accordance with the Animal Experimentation Ethics Committee at the State University of Londrina based on Federal Law 11.794 from October 8, 2008.
All the reagents used in this study were purchased from Sigma-Aldrich (St. Louis, MO, USA) unless otherwise specified.

Oocyte recovery and in vitro maturation (IVM)

Ovaries from 991 Nellore cows $(n=1982)$ were collected from a local slaughterhouse and transported to the laboratory in $0.9 \%$ saline solution at 30 $35^{\circ} \mathrm{C}$. Cumulus oophorus complexes (COCs) were aspirated from follicles up to $2 \mathrm{~mm}$ in diameter and from 4 to $8 \mathrm{~mm}$ diameter follicles with a 21 gauge (30 $8 \mathrm{~mm}$ ) hypodermic needle attached to a $10 \mathrm{~mL}$ syringe. Only oocytes surrounded by a minimum of 3 layers of cumulus cells and homogeneous cytoplasm (grades 1 and 2) (SENEDA et al., 2001) were selected for IVM (699 COCs from follicles up to $2 \mathrm{~mm}$ in diameter and 639 COCs from 4 to $8 \mathrm{~mm}$ diameter follicles). Groups of 10 to 15 COCs were cultured in a $100 \mu \mathrm{L}$ drop of maturation medium in $5 \% \mathrm{CO} 2 / 95 \%$ air and saturated humidity at $38.5^{\circ} \mathrm{C}$ for 20 to $24 \mathrm{~h}$. The maturation medium (In Vitro Brasil, Mogi Mirim, SP) consisted of bicarbonate TCM 199 supplemented with 10\% (v/v) fetal bovine serum, $5 \mu \mathrm{g}$ of luteinizing hormone, $0.5 \mu \mathrm{g}$ of follicle-stimulating hormone, $1 \mu \mathrm{g}$ of estradiol, $2.2 \mu \mathrm{g}$ of pyruvate and $50 \mu \mathrm{g} / \mathrm{mL}$ gentamicin.

\section{In vitro fertilization (IVF) and in vitro culture (IVC)}

The matured COCs were washed in HEPESbuffered medium and transferred to $100 \mu \mathrm{L}$ drops of fertilization medium (In Vitro Brasil, Mogi Mirim, SP) consisting of Tris-buffered medium supplemented with $8 \mathrm{mg} / \mathrm{mL}$ fatty acid-free bovine serum albumin (BSA) and $1 \mathrm{mM}$ glutamine.

For fertilization, sperm from a single Nellore bull that had been stored in liquid nitrogen was thawed at $35^{\circ} \mathrm{C}$ and deposited in tubes containing two different concentrations of Percoll $(300 \mu \mathrm{L}$ of a $45 \%$ Percoll gradient on top and $300 \mu \mathrm{L}$ of $90 \%$ on bottom), in which the spermatozoa were selected by centrifugation (12100 g for $2 \mathrm{~min}$ ). 
The supernatant $(600 \mu \mathrm{L})$ was discarded, and the sperm pellet was resuspended in $300 \mu \mathrm{L}$ of fertilization medium and homogenized. The semen was centrifuged again (8127 g for $45 \mathrm{~s}$ ), and after discarding the supernatant, the sperm concentration was adjusted to obtain a final concentration of $1 \times 10^{6}$ live spermatozoa $/ \mathrm{mL}$.

Sperm and COCs were co-incubated for 18 to $22 \mathrm{~h}$ in fertilization medium under mineral oil at $38.5^{\circ} \mathrm{C}$ with $5 \% \mathrm{CO}_{2}$ in air and saturated humidity.

For IVC, cumulus cells were removed from presumptive zygotes by repeated pipetting, and these zygotes were incubated in SOF (synthetic oviduct fluid; In Vitro Brasil, Mogi Mirim, SP) supplemented with $8 \mathrm{mg} / \mathrm{mL}$ fatty acid-free BSA under mineral oil at $38.5^{\circ} \mathrm{C}$ with $5 \% \mathrm{CO}_{2}$ in air and saturated humidity.

Figure 1. Experimental design.
Cleavage rates were assessed at 28, 34 and $54 \mathrm{~h}$ post-IVF.

At 3 days post-IVF, embryos were fed by exchanging $50 \%$ of the SOF medium with fresh SOF medium. At 5 days post-IVF, the embryos were fed a second time by exchanging $50 \%$ of the SOF with SOF glucoside (In Vitro Brasil, Mogi Mirim, SP).

On days 7 and 8 post-IVF, the blastocyst rates were calculated relative to the numbers of cultured presumptive zygotes and cleaved embryos.

\section{Experimental design}

Embryos were produced through 10 replicates that were divided into six groups based on the diameter of the follicle that contained the oocyte used for IVF and the onset of cleavage (Figure 1).

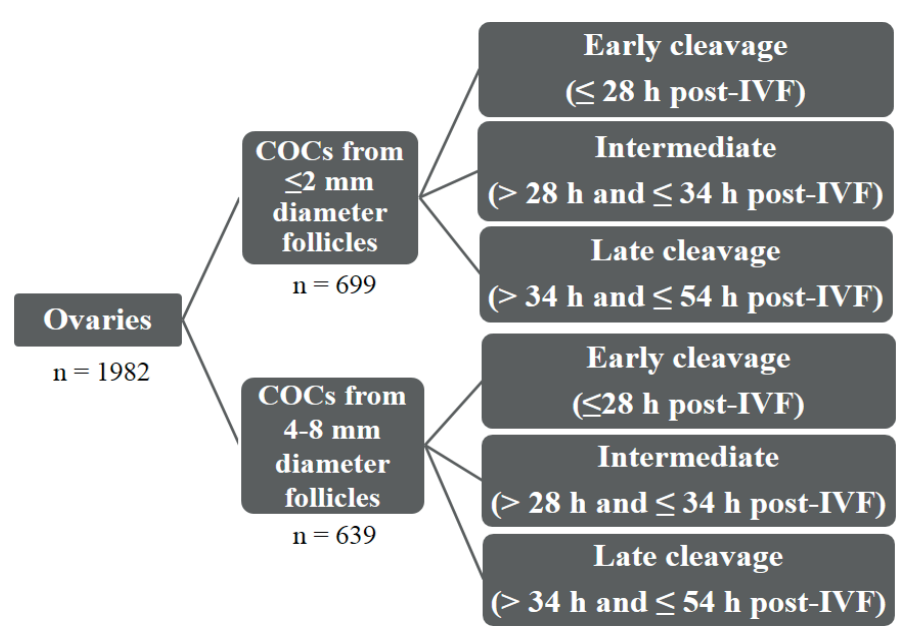

Cleavage and blastocyst rates were calculated, and the embryos were fixed at the blastocyst stage on days 7 and 8 of culture and subjected to immunofluorescence to detect $\mathrm{H} 3 \mathrm{~K} 4 \mathrm{me}$.

\section{Immunofluorescence}

The blastocysts resulting from early and late cleavage events and from $\leq 2 \mathrm{~mm}$ and $4-8 \mathrm{~mm}$ follicles were washed in phosphate-buffered saline 
(PBS), immersed in 4\% paraformaldehyde for 15 to 20 min, washed again in PBS and stored at $4{ }^{\circ} \mathrm{C}$ in $0.5 \%$ Triton $\mathrm{X}-100$ in PBS with $0.3 \%$ BSA.

Subsequently, blastocysts were incubated at $37^{\circ} \mathrm{C}$ in permeabilization solution and then washed twice (10 min each) in blocking solution (3\% BSA and $0.2 \%$ Tween-20 in PBS). Then, the blastocysts were exposed overnight at $4{ }^{\circ} \mathrm{C}$ to a primary polyclonal rabbit anti-methylated $\mathrm{H} 3 \mathrm{~K} 4$ antibody (Abcam, Cambridge, England; ab8895) diluted 1:500 in blocking solution.

The samples were then washed three times $(20$ min each) in blocking solution and incubated for $2 \mathrm{~h}$ at room temperature with a secondary goat anti-rabbit Alexa flour 488 antibody (Invitrogen, Carlsbad, CA, USA) diluted 1:1000. Subsequently, samples were washed three times (20 min each) in blocking solution and then incubated with $10 \mu \mathrm{g} /$ mL DAPI (4',6-diamidino-2-phenylindole) in PBS for DNA staining.

The embryos were placed on microscope slides with a drop of Vectashield ${ }^{\circledR}$ (Vector Laboratories, Burlingame, CA, USA) and examined using an epifluorescence microscope (Axio Imager A1, Zeiss, Jena, TH, Germany) at 100X magnification.

\section{Statistical Analysis}

The blastocyst and cleavage rates were compared by logistic regression using $\mathrm{R}$ software (R CORE TEAM, 2013). Differences were considered statistically significant at a confidence level of $95 \%$ $(\mathrm{P}<0.05)$.

\section{Results}

From the examined oocytes, a total of 1338 were selected, which 639 (47.8\%) were from 4-8 $\mathrm{mm}$ diameter follicles that gave rise to $573(89.6 \%)$ presumptive zygotes, and 699 (52.2\%) were from $\leq 2 \mathrm{~mm}$ diameter follicles that gave rise to 675 $(96.5 \%)$ presumptive zygotes.

The cleavage rate was higher for the 573 embryos from 4-8 $\mathrm{mm}$ diameter follicles $(77.5 \%)$ compared to that for the 675 embryos from the $\leq 2$ $\mathrm{mm}$ diameter follicles $(71.8 \%, \mathrm{P}<0.05$; Figure 2$)$.

The 4-8 $\mathrm{mm}$ follicle group exhibited higher blastocyst rates calculated based on the number of cultured presumptive zygotes $(28.1 \%)$ and cleaved embryos $(36.3 \%)$ than the rates for the $\leq 2 \mathrm{~mm}$ group (16.4\% and $22.9 \%$, respectively, $\mathrm{P}<0.05$; Figure 2).

Regarding the cleavage initiation time, embryos from the early $(<28 \mathrm{~h})$ and intermediate (28-34 h) groups had significantly higher blastocyst rates $(45.3 \%$ and $38.3 \%$, respectively, $\mathrm{P}<0.05)$ compared to the late cleavage group $(34-54 \mathrm{~h}$, $13.5 \%$; Figure 3).

When simultaneously analyzing follicle diameter and the timing of cleavage onset, the numbers of cleaved embryos were higher among 4-8 mm-late $(30.0 \%)$ and $\leq 2$ mm-late $(33.8 \%)$ follicles, whereas the blastocyst rates were higher in the 4-8 mm-early (50.5\%), 4-8 mm-intermediate $(45.4 \%)$ and $\leq 2$ mm-early $(40.2 \%)$ groups $(\mathrm{P}<$ 0.05 ; Table 1). 
Figure 2. Cleavage and blastocyst rates of bovine embryos produced in vitro from follicles $\leq 2 \mathrm{~mm}$ in diameter (gray column) and 4-8 $\mathrm{mm}$ in diameter (black column).

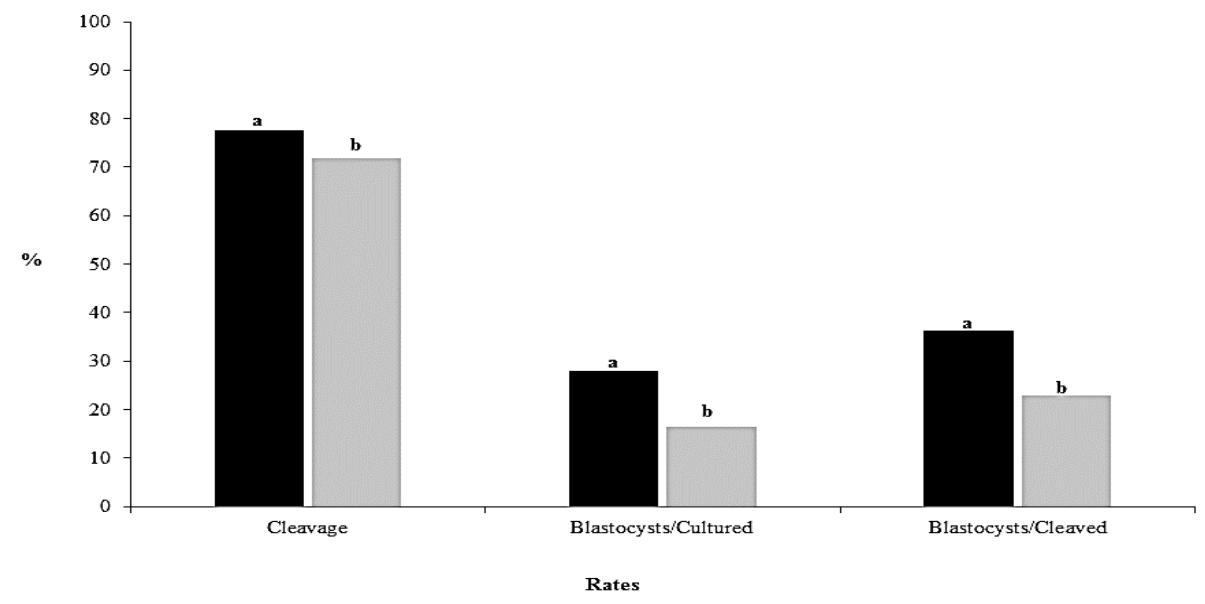

a, b: Different letters in the same category indicate a significant difference $(\mathrm{P}<0.05)$.

Figure 3. Blastocyst rates for in vitro-produced bovine embryos of early ( $\leq 28 \mathrm{~h}$; black column), intermediate ( $>28 \mathrm{~h}$ and $\leq 34 \mathrm{~h}$; light gray column) and late ( $>34 \mathrm{~h}$ and $\leq 54 \mathrm{~h}$; dark gray column) cleavage.

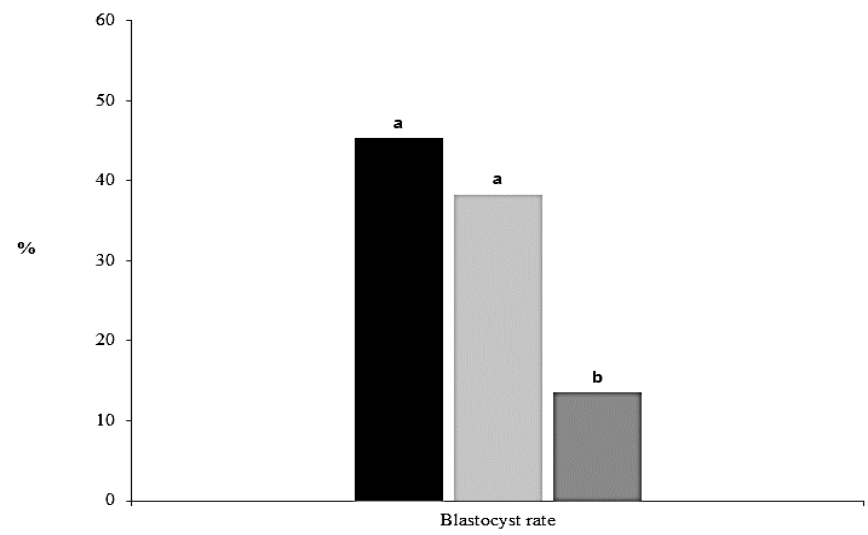

a, b: Different letters indicate a significant difference $(\mathrm{P}<0.05)$.

Table 1. Cleavage and blastocyst rates among IVP embryos generated from bovine oocytes from 4-8 $\mathrm{mm}$ or $\leq 2 \mathrm{~mm}$ diameter follicles with early $(\leq 28 \mathrm{~h})$, intermediate $(>28 \mathrm{~h}$ and $\leq 34 \mathrm{~h})$ or late $(>34 \mathrm{~h}$ and $\leq 54 \mathrm{~h})$ cleavage.

\begin{tabular}{|c|c|c|c|c|}
\hline \multirow{2}{*}{ Group } & \multicolumn{2}{|c|}{ Cleavage } & \multicolumn{2}{|c|}{ Blastocysts } \\
\hline & n & $\%$ & $\mathbf{n}$ & $\%$ \\
\hline 4-8 mm-early & 109 & $19.0^{\text {cd }}$ & 55 & $50.5^{\mathrm{a}}$ \\
\hline 4-8 mm-interm. & 163 & $28.4^{\mathrm{b}}$ & 74 & $45.4^{\mathrm{a}}$ \\
\hline 4-8 mm-late & 172 & $30.0^{\mathrm{ab}}$ & 32 & $18.6^{\mathrm{c}}$ \\
\hline$\leq 2$ mm-early & 112 & $16.6^{\mathrm{d}}$ & 45 & $40.2^{\mathrm{ab}}$ \\
\hline$\leq 2 \mathrm{~mm}$-interm. & 145 & $21.5^{\mathrm{c}}$ & 44 & $30.3^{b}$ \\
\hline$\leq 2 \mathrm{~mm}$-late & 228 & $33.8^{\mathrm{a}}$ & 22 & $9.6^{\mathrm{d}}$ \\
\hline Total & 929 & 74.4 & 272 & 29.3 \\
\hline
\end{tabular}

a, b, c, d: Different letters in the same column indicate a significant difference $(\mathrm{P}<0.05)$. 
Immunofluorescence analysis revealed that an intense $\mathrm{H} 3 \mathrm{~K} 4 \mathrm{me}$ signal in cells that appeared blastocysts from all the groups stained positively to be from the trophectoderm (TE), and the H3K4 for $\mathrm{H} 3 \mathrm{~K} 4 \mathrm{me}$ (Figure 4). Interestingly, there was staining was weak or absent in cells seemingly from the inner cell mass (ICM).

Figure 4. H3K4 monomethylation pattern in bovine blastocysts with early ( $\leq 28 \mathrm{~h}$ post-IVF) or late ( $>34 \mathrm{~h}$ and $\leq 54$ $\mathrm{h}$ post-IVF) cleavage produced in vitro using oocytes from follicles $\leq 2 \mathrm{~mm}$ or $4-8 \mathrm{~mm}$ in diameter.
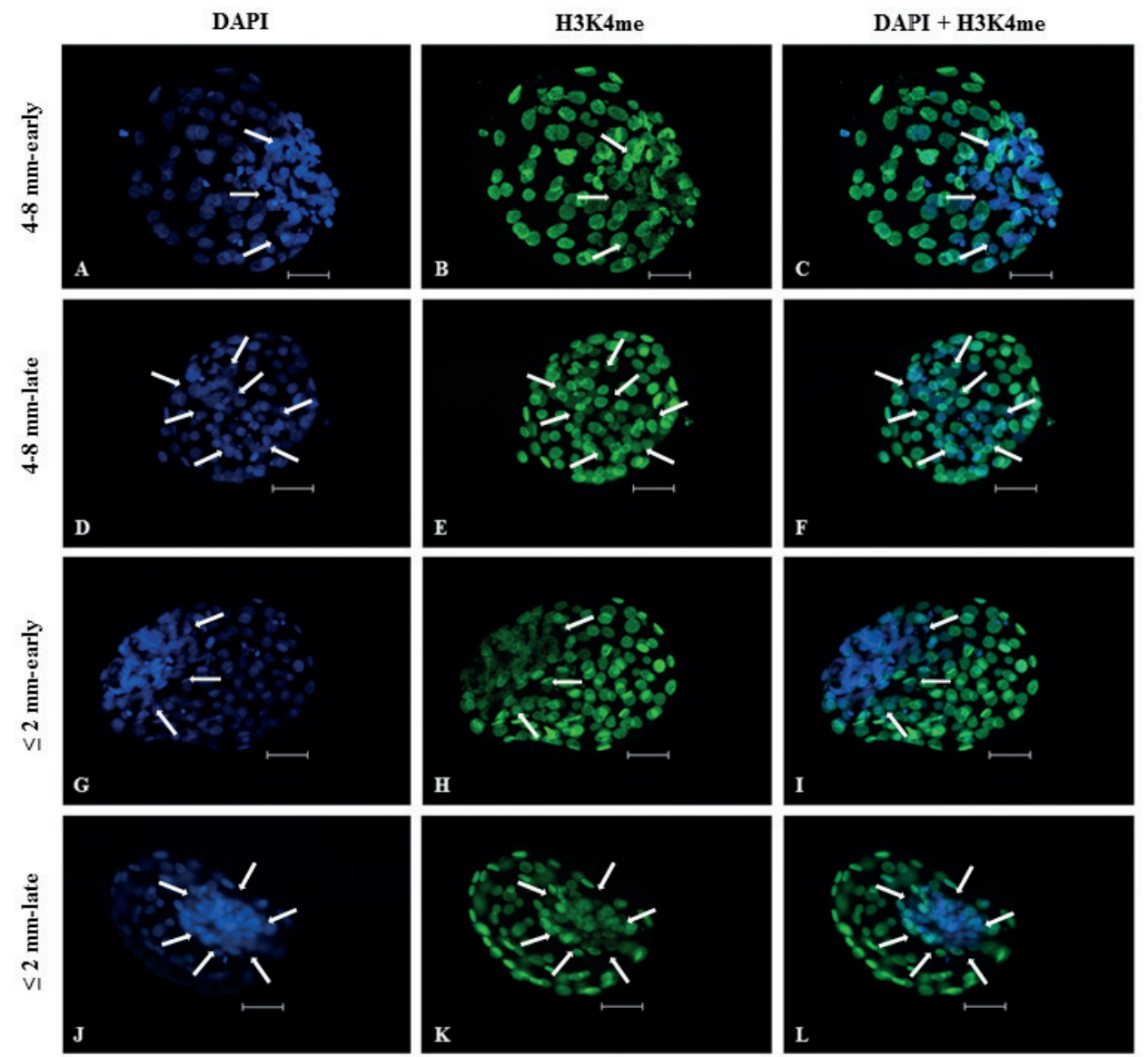

A, D, G and J: DAPI staining of blastomere nuclei in embryos from the 4-8 mm-early (A), 4-8-late (D), $\leq 2$ mm-early (G) and $\leq 2 \mathrm{~mm}$-late (J) groups. B, E, H and K: H3K4me staining in blastocysts from the 4-8 mm-early (B), 4-8-late (E), $\leq 2$ mm-early $(\mathrm{H})$ and $\leq 2 \mathrm{~mm}$-late $(\mathrm{K})$ groups. C, F, I and L: Merged H3K4me and DAPI images. White Arrows: Inner Cell Mass area. Complementing area of the embryo: Trophectoderm area. Scale bar: $100 \mu \mathrm{m}$.

\section{Discussion}

To the best of our knowledge, this is the first article describing a higher blastocyst rate from indicus embryos obtained from oocytes from a specific follicle diameter and cleaving within $34 \mathrm{~h}$ after fertilization. The combination of these characteristics may be very useful for IVF laboratories. Also, this is the first article demonstrating the occurrence of $\mathrm{H} 3 \mathrm{~K} 4 \mathrm{me}$ in cattle embryos; its presence in all the evaluated blastocysts suggests that this histone modification plays a key role in maintaining embryo viability at preimplantation stage. 
The onset of cleavage directly influenced the blastocyst rate, which was higher in early cleavage embryos, regardless of follicular diameter (4-8 mmearly: $50.5 \%$ vs. $4-8$ mm-late: $18.6 \%$; $\leq 2 \mathrm{~mm}$-early: $40.2 \%$ vs. $\leq 2$ mm-late: $9.6 \%$; and early: $45.3 \%$ vs. late: $13.5 \%$ ). Similar results were obtained by another group who observed rates of $40 \%$ (cleavage up to $30 \mathrm{~h}$ post-IVF) and $10 \%$ (cleavage $30-36 \mathrm{~h}$ post-IVF, HUMBLOT et al., 2005), which are in agreement with previous reports (ISOM et al., 2012; LECHNJAK et al., 2008; SOMFAI et al., 2010) and later studies in which late-cleaving embryos resulted in lower blastocyst and pregnancy rates (BASTOS et al., 2008; MAGLI et al., 2007; SUGIMURA et al., 2012).

The reasons why early-cleaving embryos exhibit greater viability than late-cleaving embryos have not been completely elucidated; however, it is known that embryos that complete the first cell cycle more slowly exhibit lower viability rates, are of worse quality (COUTINHO et al., 2011; DANGNGUYEN et al., 2010), and have a higher incidence of chromosomal abnormalities and mixoploidy than those that complete the cycle earlier (MAGLI et al., 2007; SUGIMURA et al., 2012). In addition, latecleaving embryos exhibit reduced expression of Interferon tau gene, which is involved in placental development and establishing and signaling maternal recognition of pregnancy in ruminants (IMAKAWA et al., 1987; ROBERTS, 1996; SOUSA et al., 2001).

The fact that the early and intermediate groups behaved similarly $(\mathrm{P}>0.05$; Table 1$)$ with regard to the blastocyst rate suggests that $34 \mathrm{~h}$ after fertilization is an important time point for evaluating cleavage to predict embryo development to the pre-implantation stage. Currently, other embryonic assessment systems exist, such as time-lapse cinematography (SUGIMURA et al., 2012), but the stereoscopic microscopy performed in this study remains the best option in terms of the cost-benefit ratio, considering its good accuracy, non-invasiveness and the lack of a requirement for special laboratory dishes and electronic recording equipment.
The resulting blastocyst rates after fertilizing oocytes from 4-8 $\mathrm{mm}$ follicles (all 4-8 $\mathrm{mm}$ follicles: $36.3 \%$; 4-8 mm-intermediate only: $45.4 \%$; and $4-8$ mm-late only: $18.6 \%)$ were higher $(\mathrm{P}<0.05)$ than those from $\leq 2 \mathrm{~mm}$ follicles (all $\leq 2 \mathrm{~mm}$ follicles: $22.9 \%$; $\leq 2$ mm-intermediate only: $30.3 \%$; and $\leq 2$ mm-late only: 9.6\%; Figure 2). The blastocyst rate for the 4-8 mm-early group although it was not statistically different, was also numerically greater $(50.5 \%)$ than that for the $\leq 2 \mathrm{~mm}$-early group (40.2\%). These results diverge from those obtained by Castilho et al. (2007), who found no significant differences, probably because they compared blastocyst rates from embryos originating from follicles $<5,5-7$ and $>7 \mathrm{~mm}$ that were obtained by ovum pick-up. Another possible explanation for this discrepancy involves the influence of culling stress on the quality of ovaries and oocytes; therefore, results from oocytes recovered in vivo and post mortem must be cautiously compared.

The results of the present study are consistent with those reported by Bastos et al. (2008) for taurus embryos; this group used bovine parthenogenetic embryos and observed blastocyst rates of $34.3 \%$ in the $4-8 \mathrm{~mm}$ follicle group and $18.9 \%$ in the $1-2$ $\mathrm{mm}$ group. These data are also in agreement with the results reported by other groups, confirming the positive influence of larger follicular diameter on development at the blastocyst stage that has been championed by many authors (HAN et al., 2006; LEQUARRE et al., 2005; LONERGAN et al., 1999). Despite the several important reproductive differences between taurus and indicus, it seems that this current point is quite similar.

The reduced competence of oocytes from small diameter follicles may be due to the inhibitory effect exerted by dominant follicles on smaller ones during the follicular wave (CASTILHO et al., 2007). Additionally, the ability of an oocyte to complete nuclear and cytoplasmic maturation and undergo embryonic development is gradually obtained up to the final stage of follicular growth (EPPIG, 2001; GONÇALVES et al., 2007). Therefore, it is possible 
that oocytes derived from larger follicles possess greater amounts of mRNA and consequently are more capable of completing the early stages of embryonic development by more easily enduring critical periods, such as the MZT.

In this study, the percentage of late-cleaving embryos was higher than the percentage of earlycleaving embryos, both for 4-8 mm follicles (4-8 mm-late: $30.0 \%$ vs. $4-8$ mm-early: $19.0 \%$ ) and $\leq$ $2 \mathrm{~mm}$ follicles ( $\leq 2 \mathrm{~mm}$-late: $33.8 \%$ vs. $\leq 2 \mathrm{~mm}$ early: $16.6 \%$; $\mathrm{P}<0.05$; Table 1 ), indicating that most embryos began the first cell division cycle at a later time point. Similar data have been reported for in vitro fertilized human embryos, with higher cleavage rates for late-cleaving embryos (25-27 h post-IVF: $96 \%$ vs. prior to $25 \mathrm{~h}$ post-IVF: $86 \%$ ) (STEIN, 2010).

When excluding the cleaving time variable (Figure 2), the results of the present study correspond with those obtained by Racedo et al. (2008) because the larger follicle group achieved a statistically higher cleavage rate $(77.5 \%)$ than the smaller follicle group (71.8\%). When comparing follicular diameter while considering the time of cleavage, the cleavage rates were similar between the 4-8 mm-early and $\leq 2 \mathrm{~mm}$-early groups and between the $4-8 \mathrm{~mm}$-late and $\leq 2 \mathrm{~mm}$-late groups and were in agreement with previously reported results from bovine (SENEDA et al., 2001) and porcine (KOHATA et al., 2013) embryos.

The present study also investigated the distribution of $\mathrm{H} 3 \mathrm{~K} 4 \mathrm{me}$ in bovine blastocysts with different cleavage onset times that were generated from oocytes from different size follicles. All the evaluated blastocysts exhibited positive staining for H3K4 monomethylation. To the best of our knowledge, this is the first article reporting the presence of $\mathrm{H} 3 \mathrm{~K} 4 \mathrm{me}$ in bovine embryos.

The fact that this epigenetic mark was strongly detected in all the evaluated embryos, regardless of the original follicular diameter or the time of cleavage onset, suggests that this histone modification is essential for blastocyst development. Interestingly, blastocysts displayed intense H3K4me staining in cells that seemed to be trophectoderm TE cells and weak or absent H3K4me staining in cells seemingly from the ICM. Such differences could be easily explained by the fact that the ICM and TE are the first two lineages of differentiated cells (ROSSANT; TAM, 2009); thus, they harbor different epigenetic codification patterns. These findings are in accordance with those obtained by Dahl et al. (2010), who reported a different pattern of H3K27 trimethylation between the ICM and TE in mouse embryos.

Although the function of $\mathrm{H} 3 \mathrm{~K} 4$ monomethylation in embryo development is not well understood, H3K4 methylation events are considered transcriptional promoters (DADA et al., 2012). Thus, higher levels of all H3K4 methylations should be observed in the ICM. However, this hypothesis is contrary to our findings. According to Degrelle et al. (2005) the expression of pluripotency genes in early cattle blastocysts is not confined to the ICM but sometimes occurs in trophoblasts. Therefore, a possible interpretation is that $\mathrm{H} 3 \mathrm{~K} 4 \mathrm{me}$ is a pluripotency epigenetic mark even in the TE.

\section{Conclusions}

Working with indicus embryos, we demonstrated that higher blastocyst rates are obtained with embryos that cleave within $34 \mathrm{~h}$ after fertilization and with those produced from 4-8 $\mathrm{mm}$ diameter follicles, indicating the enhanced ability of these embryos to develop to the stage of embryonic preimplantation. The data also demonstrated for the first time the existence of H3K4 monomethylation in bovine embryos. The presence of this epigenetic mark in all the evaluated blastocysts suggests that this histone modification plays a key role in transcriptional control at this important stage of development. 


\section{Acknowledgements}

The authors thank Prof. Célia Guadalupe Tardelli de Jesus, $\mathrm{PhD}$, from Electron Microscopy Laboratory for kindly allowing us to use the laboratory and for all the help and the Brazilian National Council for Scientific and Technological Development (CNPq) for global financial support.

\section{References}

AMIRIDIS, G. S.; CSEH, S. Assisted reproductive technologies in the reproductive management of small ruminants. Animal Reproduction Science, Amsterdam, v. 130, n. 3-4, p. 152-161, 2012.

BASTOS, G. M.; GONÇALVES, P. B. D.; BORDIGNON, $\mathrm{V}$. Immunolocalization of the high-mobility group N2 protein and acetylated histone H3K14 in early developing parthenogenetic bovine embryos derived from oocytes of high and low developmental competence. Molecular Reproduction and Development, New York, v. 75, n. 2, p. 282-290, 2008.

CASTILHO, C.; ASSIS, G. S.; GARCIA, J. M. Influência do diâmetro e da fase folicular sobre a competência in vitro de oócitos obtidos de novilhas da raça nelore. Arquivo Brasileiro de Medicina Veterinária e Zootecnia, Belo Horizonte, v. 59, n. 2, p. 288-294, 2007.

CASTRO NETO, A. S.; SANCHES, B. V.; BINELLI, M.; SENEDA, M. M.; PERRI, S. H.; GARCIA, J. F. Improvement in embryo recovery using double uterine flushing. Theriogenology, New York, v. 63, n. 5, p. 12491255, 2005.

COUTINHO, A. R. S.; ASSUMPÇÃO, M. E. O.; BORDIGNON, V. Presence of cleaved caspase 3 in swine embryos of different developmental capacities produced by parthenogenetic activation. Molecular Reproduction and Development, New York, v. 78, n. 9, p. 673-683, 2011.

CROSIER, A. E.; FARIN, P. W.; DYKSTRA, M. J.; ALEXANDER, J. E.; FARIN, C. E. Ultrastructural morphometry of bovine compact morulae produced in vivo or in vitro. Biology of Reproduction, New York, v. 62, n. 5, p. 1459-1465, 2000.

DADA, R.; KUMAR, M.; JESUDASAN, R.; FERNÁNDEZ, J. L.; GOSÁLVEZ, J.; AGARWAL, A. Epigenetics and its role in male infertility. Journal of Assisted Reproduction and Genetics, New York, v. 29, n. 3, p. 213-223, 2012.
DAHL, J. A.; REINER, A. H.; KUNGLAND, A.; WAKAYAMA, T.; COLLAS, P. Histone H3 Lysine 27 methylation asymmetry on developmentally-regulated promoters distinguish the first two lineages in mouse preimplantation embryos. Plos One, San Francisco, v. 5, n. 2, p. e9150, 2010.

DANG-NGUYEN, T. Q.; KIKUCHI, K.; SOMFAI, T.; OZAWA, M.; NAKAI, M.; MAEDOMARI, N.; VIETLINH, N.; KANAI, Y.; NGUYEN, B. X.; NAGAI, T. Evaluation of developmental competence of in vitroproduced porcine embryos based on the timing, pattern and evenness of the first cleavage and onset of the second cleavage. Journal of Reproduction and Development, Tokyo, v. 56, n. 6, p. 593-600, 2010.

DEGRELlE, S. A.; CAMPION, E.; CABAU, C.; PIUMI, F.; REINAUD, P.; RICHARD, C.; RENARD, J. P.; HUE, I. Molecular evidence for a critical period in mural trophoblast development in bovine blastocysts. Developmental Biology, San Diego, v. 288, n.2, p. 448460, 2005.

EPPIG, J. J. Oocyte control of ovarian follicular development and function in mammals. Reproduction, Cambridge, v. 122, n. 6, p. 829-838, 2001.

FAIR, T. Follicular oocyte growth and acquisition of developmental competence. Animal Reproduction Science, Amsterdam, v. 78, n. 3-4, p. 203-216, 2003.

FEIL, R. Epigenetic asymmetry in the zygote and mammalian development. International Journal of Developmental Biology, Vizcaya, v. 53, n. 2-3, p. 191201, 2009.

GANJI, R.; NABIUNI, M.; FARAJI, M. D. Development of mouse preantral follicle after in vitro culture in a medium containing melatonin. Cell Journal, Cambridge, v. 16, n. 4, p. 546-553, 2015.

GARCIA, S. M.; MARINHO, L. S. R.; LUNARDELLI, P. A.; SENEDA, M. M.; MEIRELLES, F. V. Developmental block and programmed cell death in bos indicus embryos: effects of protein supplementation source and developmental kinetics. Plos One, San Francisco, v. 10, n. 3, p. e0119463, 2015.

GONÇALVES, P. B. D.; BARRETA, M. H.; SANDRI, L. R.; FERREIRA, R.; ANTONIAZZI, A. Q. Produção in vitro de embriões bovinos: o estado da arte. Revista Brasileira de Reprodução Animal, Belo Horizonte, v. 31, n. 2, p. 212-217, 2007.

HAN, Z.-B.; LAN, G. C.; MURATA, G.; HAN, D.; FENG, W. G.; WANG, J. Z.; TAN, J. H. Interactive effects of granulosa cell apoptosis, follicle size, cumulusoocyte complex morphology, and cumulus expansion on 
the developmental competence of goat oocytes: a study using the well-in-drop culture system. Reproduction, Cambridge, v. 132, n. 5, p. 749-758, 2006.

HANSEN, P. J.; BLOCK, J.; LOUREIRO, B.; BONILLA, L.; HENDRICKS, K. E. Effects of gamete source and culture conditions on the competence of in vitro-produced embryos for post-transfer survival in cattle. Reproduction, Fertility and Development, Black Mountain, v. 22, n. 1, p. 59-66, 2010.

HUMBLOT, P.; HOLM, P.; LONERGAN, P.; WRENZYCKI, C.; LEQUARRÉ, A. S.; JOLY, C. G.; HERRMANN, D.; LOPES, A.; RIZOS, D.; NIEMANN, H.; CALLESEN, H. Effect of stage of follicular growth during superovulation on developmental competence of bovine oocytes. Theriogenology, New York, v. 63, n. 4, p. 1149-1166, 2005.

IMAKAWA, K.; ANTHONY, R. Y.; KAZEMI, M.; MAROTTI, K. R.; POLITES, H. G.; ROBERTS, R. M. Interferon-like sequence of ovine trophoblast protein secreted by embryonic trophectoderm. Nature, London, v. 330, n. 6146, p. 377-379, 1987.

ISOM, S. C.; LI, R.; WHITWIRTH, K. M.; PRATHER, R. S. Timing of first embryonic cleavage is a positive indicator of the in vitro developmental potential of porcine embryos derived from in vitro fertilization, somatic cell nuclear transfer and parthenogenesis. Molecular Reproduction and Development, New York, v. 79, n. 3, p. 197-207, 2012.

KEMPISTY, B.; WALCZAK, R.; ANTOSIK, P.; SNIADEK, P.; RYBSKA, M.; PIOTROWSKA, H.; BUKOWSKA, D.; DZIUBAN, J.; NOWICKI, M.; JAŚKOWSKI, J. M.; ZABEL, M.; BRÜSSOW, K. P. Microfluidic method of pig oocyte quality assessment in relation to different follicular size based on lab-on-chip technology. BioMed Research International, New York, v. 2014, p. 1-9, 2014.

KOHATA, C.; IZQUIERDO-RICO, M. J.; ROMAR, R.; FUNAHASHI, H. Development competence and relative transcript abundance of oocytes derived from small and medium follicles of prepubertal gilts. Theriogenology, New York, v. 80, n. 9, p. 970-978, 2013.

LABRECQUE, R.; VIGNEAULT, C.; BLONDIN, P.; SIRARD, M. A. Gene expression analysis of bovine oocytes with high developmental competence obtained from FSH stimulated animals. Molecular Reproduction and Development, New York, v. 80, n. 6, p. 428-440, 2013.

LECHNJAK, D.; PERS-KAMCZYC, E.; PAWLAK, P. Timing of the first zygotic cleavage as a marker of developmental potential of mammalian embryos.
Reproductive Biology, Amsterdam, v. 8, n. 1, p. 23-42, 2008.

LEQUARRE, A. S.; MARCHANDISE, J.; MOREAU, B.; MASSIP, A.; DONNAY, I. Cell cycle duration at the time of maternal zygotic transition for in vitro Produced bovine embryos: effect of oxygen tension and transcription inhibition. Biology of Reproduction, New York, v. 69, n. 5, p. 1707-1713, 2003.

LEQUARRE, A.-S.; VIGNERON, C.; RIBAUCOUR, F.; HOLM, P.; DONNAY, I.; DALBIÈS-TRAN, R.; CALLESEN, H.; MERMILLOD, P. Influence of antral follicle size on oocyte characteristics and embryo development in the bovine. Theriogenology, New York, v. 63, n. 3, p. 841-859, 2005.

LONERGAN, P.; KHATIR, H.; PIUMI, F.; RIEGER, D.; HUMBLOT, P.; BOLAND, M. P. Effect of time interval from insemination to first cleavage on the developmental characteristics, sex ratio and pregnancy rate after transfer of bovine embryos. Journal of Reproduction and Fertility, Oxford, v. 117, n. 1, p. 159-167, 1999.

MAGLI, M. C.; GIANAROLI, L.; FERRARETTI, A. P.; LAPPI, M.; RUBERTI, A.; FARFALLI, V. Embryo morphology and development are dependent on the chromosomal complement. Fertility and Sterility, New York, v. 87, n. 3, p. 534-541, 2007.

NIVET, A. L.; VIGNEAULT, C.; BLONDIN, P.; SIRARD, M. A. Changes in granulosa cells' gene expression associated with increased oocyte competence in bovine. Reproduction, Cambridge, v. 145, n. 6, p. 555$565,2013$.

PONTES, J. H. F.; MELO-STERZA, F. A.; BASSO, A. C.; FERREIRA, C. R.; SANCHES, B. V.; RUBIN, K. C.; SENEDA, M. M. Ovum pick up, in vitro embryo production, and pregnancy rates from a large-scale commercial program using Nelore cattle (Bos indicus) donors. Theriogenology, New York, v. 75, n. 9, p. 16401646, 2011.

PONTES, J. H.; SILVA, K. C.; BASSO, A. C.; RIGO, A. G.; FERREIRA, C. R.; SANTOS, G. M.; SANCHES, B. V.; PORCIONATO, J. P.; VIEIRA, P. H.; FAIFER, F. S.; STERZA, F. A.; SCHENK, J. L.; SENEDA, M. M. Large-scale in vitro embryo production and pregnancy rates from Bos taurus, Bos indicus, and indicus-taurus dairy cows using sexed sperm. Theriogenology, New York, v. 74, n. 8, p. 1349-1355, 2010.

R CORE TEAM - R: a language and environment for statistical computing. R Foundation for Statistical Computing. Vienna: The R Foundation, 2013. Available at: <http://www.R-project.org/>. Accessed at: 19 out. 2015. 
RACEDO, S. E.; WRENSYCKI, C.; HERRMENN, D.; SALAMONE, D.; NIEMANN, H. Effects of follicle size and stages of Maturation on mRNA expression in bovine in vitro matured oocytes. Molecular Reproduction and Development, New York, v. 75, n. 1, p. 17-25, 2008.

RIVERA, R. M.; ROSS, J. W. Epigenetics in fertilization and preimplantation embryo development. Progress in Biophysics and Molecular Biology, Oxford, v. 113, n. 3, p. 423-432, 2013.

ROBERTS, R. M. Interferon-tau and pregnancy. Journal of Interferon and Cytokine Research, New York, v. 16, n. 4, p. 271-273, 1996.

RODRIGUES, J. K.; NAVARRO, P. A.; ZELINSKI, M. B.; STOUFFER, R. L.; XU, J. Direct actions of androgens on the survival, growth and secretion of steroids and anti-müllerian hormone by individual macaque follicles during three-dimensional culture. Human Reproduction, London, v. 30, n. 3, p. 664-674, 2015.

RODRÍGUEZ-DORTA, N.; COGNIE, Y.; GONZÁLES, F.; POULIN, N.; GUIGNOT, F.; TOUZÉ, J. L.; BARIL, G.; CABRERA, F.; ALAMO, D.; BATISTA, M.; GRACIA, A.; MERMILLOD, P. Effect of co-culture with oviduct epithelial cells on viability after transfer of vitrified in vitro produced goat embryos. Theriogenology, New York, v. 68, n. 6, p. 908-913, 2007.

ROSSANT, J.; TAM, P. P. Blastocyst lineage formation, early embryonic asymmetries and axis patterning in the mouse. Development, Cambridge, v. 136, n. 5, p. 701713, 2009.

SENEDA, M. M.; ESPER, C. R.; GARCIA, J. M.; OLIVEIRA, J. A.; VANTINI, R. Relationship between follicle size and ultrasound-guided transvaginal oocyte recovery. Animal Reproduction Science, Amsterdam, v. 67, n. 1-2, p. 37-43, 2001.

SENEDA, M. M.; GODMANN, M.; MURPHY, B.; KIMMINS, S.; BORDIGNON, V. Developmental regulation of histone $\mathrm{H} 3$ methylation at lysine 4 in the porcine ovary. Reproduction, Cambridge, v. 135, n. 6, p. 829-838, 2008.

SHABANKAREH, H. K.; AZIMI, G.; TORKI, M. Developmental competence of bovine oocytes selected based on follicle size and using the brilliant cresyl blue (bcb) test. Iranian Journal of Reproductive Medicine, Yazd, v. 12, n. 11, p. 771-778, 2014.
SILVA-SANTOS, K. C.; SILOTO, L. S.; SANTOS, G. M.; MOROTTI, F.; MARCANTONIO, T. N.; SENEDA, M. M. Comparison of antral and preantral ovarian follicle populations between bos indicus and bos indicustaurus cows with high or low antral follicles counts. Reproduction in Domestic Animals, New York, v. 49, n. 1, p. 48-51, 2014.

SOMFAI, T.; INABA, Y.; AIKAWA, Y.; OHTAKE, M.; KOBAYASHI, S.; KONISHI, K.; IMAI, K. Relationship between the length of cell cycle, cleavage patterns and developmental competence in bovine embryos generated by in vitro fertilization or parthenogenesis. Journal of Reproduction and Development, Tokyo, v. 56, n. 2, p. 200-207, 2010.

SOUSA, P. A.; KING, T.; HARKNESS, L.; YOUNG, L. E.; WALKER, S. K.; WILMUT, I. Evaluation of gestational deficiencies in cloned sheep fetuses and placentae. Biology of Reproduction, New York, v. 65, n. 1, p. 23-30, 2001.

STEIN, A. C. Avaliação dos parâmetros seminais no desenvolvimento embrionário em mulheres submetidas à fertilização in vitro com estimulação ovariana. Porto Alegre: Universidade Federal do Rio Grande do Sul, 2010. 83 p.

SUDANO, M. J.; SANTOS, V. G.; TATA, A.; FERREIRA, C. R.; PASCHOAL, D. M.; MACHADO, R.; BURATINI, J.; EBERLIN, M. N.; LANDIM-ALVARENGA, F. D. Phosphatidylcholine and sphingomyelin profiles vary in Bos taurus indicus and Bos taurus taurus in vitro- and in vivo-produced blastocysts. Biology of Reproduction, New York, v. 87, n. 6, p. 130-140, 2012.

SUGIMURA, S.; AKAI, T.; HASHIYADA, Y.; SOMFAI, T.; INABA, Y.; HIRAYAMA, M.; YAMANOUCHI, T.; MATSUDA, H.; KOBAYASHI, S.; AIKAWA, Y.; OHTAKE, M.; KOBAYASHI, E.; KONISHI, K.; IMAI, $\mathrm{K}$. Promising system for selecting healthy in vitrofertilized embryos in cattle. Plos One, San Francisco, v. 7, n. 5, p. e36627, 2012.

YOSHIOKA, K.; NOGUCHI, M.; SUZUKI, C. Production of piglets from in vitro-produced embryos following non-surgical transfer. Animal Reproduction Science, Amsterdam, v. 131, n. 1-2, p. 23-29, 2012. 